\title{
UPAYA MENINGKATKAN HASIL BELAJAR SISWA MELALUI PENERAPAN MODEL PEMBELAJARANSTAD PADA MATA PELAJARAN IPA DI KELAS VIII.B SMP NEGERI 3 BAHOROK
}

\author{
Suwardi \\ Guru Mata Pelajaran IPA di SMP Negeri 3 Bahorok \\ Surel : zahratazkia06@gmail.com
}

\begin{abstract}
Efforts to Improve Student Results Through Application of Learning Model STAD On Subjects Science Classroom VIII.B SMP Negeri 3 Bahorok. This study aims to determine the increased activity of learning and student learning outcomes in mathematics by applying cooperative learning model of type Student Team Achievement Division (STAD) in the class VIII.B SMP Negeri 3 Bahorok Learning Years 2016/2017. This classroom action research will be pursued in two cycles. From cycle to cycle using cooperative learning model of type Student Team Achievement Division (STAD) with constantly improving learning activities and student learning outcomes. Research grade students VIII.B imposed on SMP Negeri 3 Bahorok by the number of 26 students. After the study lasted for two cycles can be concluded that an increase learning outcomes and student activity for teachers to assign work to students for the kingdom at home, it makes students better understand learning and also for each student already has the responsibility of each so that the learning goes according which are expected.
\end{abstract}

Keywords: Learning Model (STAD), Student Learning, Learning Activities

\begin{abstract}
Abstrak : Upaya Meningkatkan Hasil Belajar Siswa Melalui Penerapan Model Pembelajaran STAD Pada Mata Pelajaran IPA Di Kelas VIII.B SMP Negeri 3 Bahorok. Penelitian ini bertujuan untuk mengetahui peningkatan aktivitas belajar dan hasil belajar siswa dalam pembelajaran matematika dengan menerapkan model pembelajaran koperatif tipe Student Team Achievement Division (STAD) di kelas VIII.B SMP Negeri 3 Bahorok Tahun Pembelajaran 2016/2017. Penelitian tindakan kelas ini akan ditempuh dalam dua siklus. Dari siklus ke siklus menggunakan model pembelajaran koperatif tipe Student Team Achievement Division (STAD) dengan senantiasa meningkatkan aktivitas belajar dan hasil belajar siswa. Penelitian dikenakan pada siswa kelas VIII.B SMP Negeri 3 Bahorok dengan jumlah 26 siswa. Setelah penelitian berlangsung selama dua siklus dapat disimpulkan bahwa terjadi peningkatan hasil belajar dan aktivitas siswa karena guru memberikan tugas kepada siswa untuk dikerjaan di rumah, hal ini membuat siswa semakin memahami pembelajaran dan juga karena setiap siswa sudah memiliki tanggung jawab masingmasing sehingga pembelajaran berjalan sesuai yang diharapkan.
\end{abstract}

Kata Kunci : Model pembelajaran STAD, Hasil Belajar Siswa, Aktivitas Belajar

\section{PENDAHULUAN}

Berdasarkan pengalaman mengajar IPA selama \pm 19 tahun banyak kendala yang dihadapi pada saat mengajarkan IPA khususnya di kelas VIII.B SMP Negeri 3 Bahorok. Hal ini disebabkan karena $62.5 \%$ siswa belajar dengan cara menghafal tanpa membentuk pengertian terhadap materi yang dipelajari, kemudian pada saat mempelajari IPA siswa sudah mengenal beberapa organ yang terlibat dalam proses pencernaan dan pernafasan. Namun pada saat ditanyakan letak-letak organ tersebut sebagian besar siswa tidak mampu menjawab, dan siwa kelas VIII.B juga kesulitan dalam membedakan tenggorokan dengan kerongkongan padahal guru sudah menjelaskan melalui gambar letak dan nama organ. Hal ini terjadi karena siswa tidak fokus pada pembelajaran yang 
sedang diajarkan guru sehingga apa yang disampaikan guru tidak dapat dipahami siswa. Ketidakfokusan siswa juga disebabkan karena siswa kurang berminat atau kurang termotivasi untuk mempelajari IPA. Selain itu, aktivitas siswa kelas VIII.B juga masih minim dimana hanya 3 siswa yang mampu mengajukan pertanyaan atau menjawab pertanyaan yang diberikan sedangkan siswa yang lain walaupun mereka tidak mengerti, mereka hanya diam saja. Kurangnya keterlibatan siswa dalam pembelajaran ini menyebabkan hasil ulangan siswa kelas VIII.B rendah dimana dari 26 siswa hanya 10 siswa $(38.5 \%)$ yang mencapai KKM yang ditentukan.

Dengan adanya deskripsi diatas, maka diperlukan suatu pembenahan dalam upaya meningkatkan hasil belajar siswa dengan melakukan perbaikan pada aktivitas belajar siswa. Salah satu cara membenahinya yaitu dengan menerapkan suatu model pembelajaran yang dapat membuat siswa berdiskusi, berpikir kritis, berani dan mau mengambil tanggung jawab untuk pembelajaran mereka sendiri Salah sattu model yang cocok dengan permasalahan di atas adalah model pembelajaran kooperatif tipe STAD.

Berdasarkan latar belakang di atas, maka yang menjadi rumusan masalah dalam penelitian ini adalah; 1) Apakah terjadi peningkatan hasil belajar siswa pada mata pelajaran IPA dengan menerapkan model pembelajaran Student Teams Achievement Division di kelas VIII.B SMP Negeri 3 Bahorok?; 2) Apakah terjadi peningkatan aktivitas belajar siswa pada mata pelajaran IPA dengan menerapkan model pembelajaran Student Teams Achievement Division di kelas VIII.B SMP Negeri 3 Bahorok?

\section{METODE}

Penelitian ini dilakukan di SMP Negeri 3 Bahorok yang beralamat di Jalan Datuk Marpelas Desa Tanjung Lenggang Kecamatan Bahorok Kabupaten Langkat dan pelaksanaannya selama 4 bulan mulai dari bulan September 2016 sampai dengan Desember 2016.

Subjek penelitian adalah siswa kelas VIII.B SMP Negeri 3 Tahun Pembelajaran 2016/2017 dengan jumlah siswa yang terikut dalam penelitian sebanyak 26 siswa.

Alat pengumpul data dalam penelitian ini adalah berupa tes hasil belajar dan observasi. Tes hasil belajar ini digunakan untuk mengetahui kemampuan siswa pada tingkat kognitif siswa tiap siklus dan observasi dilakukan untuk mengetahui aktivitas siswa selama diskusi kelompok.

Penelitian ini berbentuk Penelitian Tindakan Kelas (PTK). PTK pertama kali diperkenalkan oleh psikologi sosial Amerika yang bernama Kurt Lewin pada tahun 1946 (Aqib, 2006). Penelitian tindakan kelas adalah penelitian yang dilakukan oleh guru di kelas atau di sekolah dengan penekanan pada penyempurnaan atau peningkatan proses pembelajaran. Menurut Lewin dalam Aqib (2006) menyatakan bahwa dalam satu siklus terdiri atas empat langkah, yaitu perencanaan (planning), tindakan (acting), observasi (observing) dan refleksi (reflecting).

Metode analisis data pada penelitian ini digunakan metode deskriptif dengan membandingkan hasil belajar siswa sebelum tindakan dengan hasil belajar siswa setelah tindakan.

Langkah-langkah pengolahan data sebagai berikut: 
1) Merekapitulasi nilai pretes sebelum tindakan dan nilai tes akhir siklus I dan siklus II

2) Menghitung nilai rata-rata atau persentase hasil belajar siswa sebelum dilakukan tindakan dengan hasil belajar setelah dilakukan tindakan pada siklus I dan siklus II untuk mengetahui adanya peningkatan hasil belajar.

3) Penilaian

a. Data nilai hasil belajar diperoleh dengan menggunakan rumus:

Nilai Siswa $=\frac{\text { jawaban y ang benar }}{\text { jumlah soal }} \times 1$ (dognitif

(Slameto, 2001)

b. Nilai rata-rata siswa dicari dengan rumus sebagai berikut:

$$
\bar{X}=\frac{\sum X}{N}
$$

Keterangan :

$$
\begin{aligned}
& \bar{X}=\text { Nilai rata-rata } \\
& \Sigma=\text { Jumlah nilai } X \\
& \mathrm{~N}=\text { Jumlah peserta tes }
\end{aligned}
$$

(Subino, 1987)

c. Untuk penilaian aktivitas digunakan rumus sebagai berikut:

Setelah data aktivitas siswa terkumpul sesuai dengan jumlah kegiatan belajar mengajar, maka data tersebut disusun kemudian data tersebut dirubah menjadi data prosentase. Untuk menganalisis data-data tersebut kemudian dianalisis dengan proporsi aktivitas.

$\%$ ProporsiAktivitas $=\frac{\text { jumlah skor yang diperoleh }}{\text { jumlah skor ideal }} \times 100 \%$

(Majid,2009)

Sebagai tolak ukur peningkatan aktivitas belajar siswa yang sesuai dengan rumusan masalah dapat dilihat dari meningkatnya rata-rata aktivitas mengerjakan LKS, bertanya pada teman dan penurunan aktivitas membaca, bertanya pada guru dan kegiatan yang tidak relevan dengan KBM.

b. Ketentuan persentase ketuntasan belajar kelas

Ketuntasan belajar kelas $=\frac{\sum \mathrm{S}_{\mathrm{b}}}{\mathrm{K}} \times 100 \%$

$\Sigma \mathrm{Sb}=$ Jumlah siswa yang

nilai $\geq 75$

$\Sigma \mathrm{K}=$ Jumlah siswa dalam subjek

Sebagai tolak ukur peningkatan hasil belajar siswa sesuai dengan rumusan masalah pada bab I dapat dilihat dari hasil formatif I dan formatif II dengan cara membandingkan jumlah siswa yang tuntas secara individu dan kelas.

Berkaitan dengan indikator kinerja Suwandi dan Madyo Eko Susilo (2007:36) menyatakan bahwa "Indikator kinerja merupakan rumusan kinerja yang akan dijadikan dalam menentukan keberhasilan atau keefektifan penelitian. Dalam penelitian ini indikator pencapaian apabila nilai siswa secara individu mencapai KKM IPA kelas VIII.B yang ditetapkan sekolah sebesar 75 dan secara klasikal $\geq 85 \%$ siswa mencapai KKM tersebut.

\section{PEMBAHASAN}

Penelitian ini dilaksanakan dalam dua siklus. Masing-masing siklus dilaksanakan dua kali pertemuan, pertemuan digunakan untuk pembahasan materi dengan alokasi waktu 2 x 40 menit, dan sebagian pertemuan akhir siklus digunakan untuk evaluasi dengan 
alokasi waktu 10 menit. Hal ini disesuaikan dengan jadwal pelajaran IPA.

Sebelum dilaksanakan Siklus I dilakukan uji awal untuk menjajaki kemampuan awal siswa. Hasil pretes menunjukkan nilai dengan rata-rata 20.4 dan nilai terendah 10 diperoleh 4 orang siswa dan tertinggi 30 diperoleh 5 orang siswa. Dengan ketuntasan minimal (KKM) sebesar 75 maka ketuntasan klasikal hanya sebesar 0\%.

Pada akhir siklus I dilakukan tes Formatif I untuk mengetahui kemampuan siswa dalam memahami materi pada siklus I. Nilai hasil Formatif I dalam Siklus I disajikan dalam Tabel.

Tabel Deskripsi Data Formatif I

\begin{tabular}{|c|c|c|}
\hline Nilai & Frekuensi & Rata-rata \\
\hline 40 & 2 & \multirow{3}{*}{70.8} \\
\cline { 1 - 2 } 60 & 10 & \multirow{2}{*}{70.} \\
\hline 80 & 12 & \\
\hline 100 & 2 & \\
\cline { 1 - 2 } Jumlah & 26 & \\
\hline
\end{tabular}

Siklus I dilakukan selama dua KBM yaitu KBM I dan KBM II. Pada saat melaksanakan pembelajaran dua pengamat merekam aktivitas siswa sesuai dengan instruksi oleh peneliti. Hasil rekaman yang dilakukan oleh pengamat diserahkan kembali kepada peneliti untuk dianalisis. Hasil analisis rekaman aktivitas siswa dari pengamat selama siklus I dapat disajikan dalam Tabel.

Tabel Skor Rata-Rata Aktivitas Belajar Siswa Siklus I

\begin{tabular}{|c|l|c|}
\hline No & \multicolumn{1}{|c|}{ Aktivitas } & Persentase \\
\hline & Menulis, & \\
1 & Membaca & $41.00 \%$ \\
\hline 2 & Mengerjakan LKS & $23.00 \%$ \\
\hline 3 & Bertanya pada & $9.00 \%$ \\
\hline
\end{tabular}

\begin{tabular}{|c|l|c|} 
& teman & \\
\hline 4 & Bertanya pada guru & $16.50 \%$ \\
\hline 5 & $\begin{array}{l}\text { Yang tidak relevan } \\
\text { dengan KBM }\end{array}$ & $10.50 \%$ \\
\hline \multicolumn{2}{|c|}{ Jumlah } & $100.00 \%$ \\
\hline
\end{tabular}

Merujuk pada hasil belajar, aktivitas belajar dan dokumentasi penelitian, belum tercapainya hasil belajar siswa pada ketuntasan klasikal disebabkan oleh :

1. Sebagian siswa masih belum terbiasa dengan alur pembelajaran atau masih bingung selama pelaksanaan kegiatan.

2. Sebagian siswa belum memiliki rasa tanggung jawab terhadap tugasnya dalam kelompok, di setiap kelompok siswa masih ada anggota kelompok yang menyerahkan permasalahan kepada anggota kelompoknya dan tidak mau tau, bahkan ada beberapa siswa yang menciptakan kegaduhan dalam kelompoknya.

3. Terlalu singkat waktu diskusi yang diberikan sehingga aktivitas diskusi tampak terburu-buru, apalagi waktu diskusi terpakai untuk kelompok mempelajari LKS, sehingga waktu pengerjaan LKS semakin sedikit.

4. Masih terjadi kesalahan-kesalahan dalam mengerjaan LKS dan penarikan kesimpulan oleh siswa yang menandakan terjadi miskonsepsi dalam diskusi kelompok.

Pada akhir melaksanakan siklus II, dilakukan tes Formatif II untuk mengetahui pemahaman siswa tentang materi yang diajarkan dengan menerapkan model pembelajaran kooperatif tipe STAD. Hasil Formatif II pada Siklus II disajikan dalam Tabel. 
Tabel Deskripsi Data Formatif II

\begin{tabular}{|c|c|c|}
\hline Nilai & Frekuensi & Rata-rata \\
\hline 60 & 3 & \\
\cline { 1 - 2 } 80 & 19 & \multirow{2}{*}{80.8} \\
\cline { 1 - 2 } 100 & 4 & \\
\cline { 1 - 2 } Jumlah & 26 & \\
\hline
\end{tabular}

Siklus II dilakukan selama dua KBM yaitu KBM III dan KBM IV. Pada saat melaksanaan KBM dua pengamat merekam aktivitas siswa sesuai dengan instruksi oleh peneliti. Hasil rekaman yang dilakukan oleh pengamat diserahkan kembali kepada peneliti untuk dianalisis. Hasil analisis rekaman aktivitas siswa dari pengamat selama siklus II dapat disajikan dalam Tabel.

Tabel Skor Rata-Rata Aktivitas Belajar Siswa Siklus II

\begin{tabular}{|c|l|c|}
\hline No & Aktivitas & Persentase \\
\hline 1 & $\begin{array}{l}\text { Menulis, } \\
\text { Membaca }\end{array}$ & $22.38 \%$ \\
\hline 2 & Mengerjakan LKS & $45.24 \%$ \\
\hline 3 & Bertanya pada teman & $20.48 \%$ \\
\hline 4 & Bertanya pada guru & $8.10 \%$ \\
\hline 5 & $\begin{array}{l}\text { Yang tidak relevan } \\
\text { dengan KBM }\end{array}$ & $3.81 \%$ \\
\hline & Jumlah & $100.00 \%$ \\
\hline
\end{tabular}

Pada Siklus II guru telah menerapkan model pembelajaran tipe STAD dengan baik dan dilihat dari aktifitas siswa serta hasil belajar siswa pelaksanaan proses belajar mengajar sudah berjalan dengan baik. Maka tidak diperlukan revisi terlalu banyak, tetapi yang perlu diperhatikan untuk tindakah selanjutnya adalah memaksimalkan dan mepertahankan apa yang telah ada dengan tujuan agar pada pelaksanaan proses belajar mengajar selanjutnya penerapan pembelajaran tuntas dapat meningkatkan proses belajar mengajar sehingga tujuan pembelajaran dapat tercapai. Akan tetapi karena keterbatasan biaya dan waktu dalam desain penelitian maka penelitian direncanakan dalam dua siklus saja.

Penelitian ini dilaksanakan dalam dua siklus. Masing-masing siklus dilaksanakan dua kali pertemuan, pertemuan digunakan untuk pembahasan materi dengan alokasi waktu 2 x 40 menit, dan sebagian pertemuan akhir siklus digunakan untuk evaluasi dengan alokasi waktu 10 menit. Hal ini disesuaikan dengan jadwal pelajaran IPA. Sebelum dilaksanakan Siklus I dilakukan uji awal untuk menjajaki kemampuan awal siswa. Hasil pretes menunjukkan nilai dengan rata-rata 20.4 dan nilai terendah 10 diperoleh 4 orang siswa dan tertinggi 30 diperoleh 5 orang siswa. Dengan ketuntasan minimal (KKM) sebesar 75 maka ketuntasan klasikal hanya sebesar $0 \%$.

Setelah diketahui kondisi awal siswa dilanjutkan dengan pelaksanaan siklus I yang dilakukan selama dua KBM yaitu KBM I dan KBM II. pada akhir siklus I dilakukan tes Formatif I untuk mengetahui kemampuan siswa dalam memahami materi pada siklus I. Nilai hasil Formatif I dalam Siklus I merujuk Tabel 4.1. nilai terendah 40 sebanyak 2 siswa dan yang mendapat nilai 100 sebanyak 2 orang. Nilai ratarata 70.8 dengan KKM 75, jumlah siswa tuntas 14 dari 26 siswa. Hal ini menunjukkan hasil belajar siswa masih rendah. Hasil tersebut menunjukkan bahwa pada Siklus I secara klasikal, siswa belum tuntas belajar, karena siswa yang memahami materi yang telah disampaikan hanya sebesar 54\% lebih kecil dari persentase ketuntasan yang dikehendaki yaitu sebesar $85 \%$.

Pada saat melaksanakan pembelajaran dua pengamat merekam aktivitas siswa sesuai dengan instruksi 
oleh peneliti. Hasil rekaman yang dilakukan oleh pengamat diserahkan kembali kepada peneliti untuk dianalisis. Hasil analisis rekaman aktivitas siswa dari pengamat selama siklus I merujuk Tabel 4.2. diperoleh aktivitas yang paling dominan adalah menulis/membaca (41.00\%), diposisi kedua adalah aktivitas mengerjakan LKS (23.00\%), dilanjutkan dengan aktivitas bertanya pada guru (16.50\%), yang tidak relevan dengan KBM $10.50 \%$ dan terakhir aktivitas bertanya pada teman dengan proporsi $9.00 \%$. Tingginya aktivitas yang tidak relevan dikarenakan saat pembelajaran berlangsung siswa belum biasa menangkap alur dan konsep yang diberikan guru saat pembelajaran. Hal ini terlihat dari selama proses pembelajaran sebagian siswa hanya sibuk dengan kegiatan mereka masingmasing meskipun guru sudah menegur mereka. Saat presentasi kelompok, masih banyak siswa yang salah dalam menarik kesimpulan.

Merujuk pada hasil belajar, aktivitas belajar dan dokumentasi penelitian, belum tercapainya hasil belajar siswa pada ketuntasan klasikal disebabkan oleh :

1. Sebagian siswa masih belum terbiasa dengan alur pembelajaran atau masih bingung selama pelaksanaan kegiatan.

2. Sebagian siswa belum memiliki rasa tanggung jawab terhadap tugasnya dalam kelompok, di setiap kelompok siswa masih ada anggota kelompok yang menyerahkan permasalahan kepada anggota kelompoknya dan tidak mau tau, bahkan ada beberapa siswa yang menciptakan kegaduhan dalam kelompoknya.
3. Terlalu singkat waktu diskusi yang diberikan sehingga aktivitas diskusi tampak terburu-buru, apalagi waktu diskusi terpakai untuk kelompok mempelajari LKS, sehingga waktu pengerjaan LKS semakin sedikit.

4. Masih terjadi kesalahan-kesalahan dalam mengerjaan LKS dan penarikan kesimpulan oleh siswa yang menandakan terjadi miskonsepsi dalam diskusi kelompok.

Sebelum melanjutkan siklus II, peneliti berdiskusi dengan guru sejawat dan pengamat untuk memperbaiki proses pembelajaran supaya siklus II dapat berhasil meningkatkan hasil belajar dan aktivitas siswa. Hasil diskusi perbaikan yang akan dilakukan pada Siklus II adalah sebagai berikut:

1) Untuk membantu siswa menyesuaikan diri dalam alur pembelajaran maka sebelum pembelajaran berlangsung guru akan menjelaskan terlebih dahulu desain pembelajaran sesuai dengan model pembelajaran kooperatif tipe STAD.

2) Untuk memunculkan rasa tanggung jawab masing-masing siswa maka tiap kelompok dibantu dalam membagi spesifikasi siswa dalam tugas masing-masing dan memberi peringatan bahwa tiap siswa akan ditagih pekerjaanya dalam kegiatan bertanya.

3) Untuk menyiasati masalah waktu, maka guru akan membagikan LKS sebelum KBM dilaksanakan. Hal ini agar siswa dapat mempersiapkan diri dari rumah tentang bahan diskusi adan agar siswa dapat langsung bekerja ketika diberi waktu diskusi.

4) Untuk menyiasati masalah kesulitan siswa menarik kesimpulan dan 
mengatasi miskonsepsi, guru akan memberikan pertanyaan pancingan kepada siswa dengan menunjuk beberapa siswa untuk menjawab. Keseluruhan dari pernyataan siswa tersebut kemudian disaring dan diberi penjelasan oleh guru jika masih ada yang belum paham. Selanjutnya akan ditarik kesimpulan bersama sehingga siswa bisa lebih mengerti apa yang telah mereka kerjakan dalam kelompok masing-masing.

Setelah diketahui tindakan perbaikan, maka peneliti melanjutkan penelitian ke siklus II yang dilakukan selama dua KBM yaitu KBM III dan KBM IV. Pada akhir melaksanakan siklus II, dilakukan tes Formatif II untuk mengetahui pemahaman siswa tentang materi yang diajarkan dengan menerapkan model pembelajaran kooperatif tipe STAD. Hasil Formatif II pada Siklus II merujuk Tabel dengan nilai terendah 60 sebanyak 3 siswa dan yang mendapat nilai 100 sebanyak 4 orang. Nilai rata-rata 80.8 dengan KKM 75 , jumlah siswa tuntas 23 dari 26 siswa. Hal ini menunjukkan hasil belajar siswa sudah meningkat. Hasil tersebut menunjukkan bahwa pada Siklus II secara klasikal siswa sudah tuntas belajar, karena siswa yang memahami materi yang telah disampaikan sebesar 88\% lebih besar dari persentase ketuntasan yang dikehendaki yaitu sebesar $85 \%$. Peningkatan hasil belajar ini disebabkan karena guru memberikan siswa tugas di rumah yang bertujuan supaya siswa mengulang pelajaran. Hal ini membuat siswa semakin memahami pembelajaran.

$$
\text { Kemudian pada saat }
$$

melaksanaan KBM dua pengamat merekam aktivitas siswa sesuai dengan instruksi oleh peneliti. Hasil rekaman yang dilakukan oleh pengamat diserahkan kembali kepada peneliti untuk dianalisis. Hasil analisis rekaman aktivitas siswa dari pengamat selama siklus II merujuk Tabel dimana aktivitas yang dominan adalah mengerjakan LKS (45.24\%). Di posisi kedua aktivitas menulis,membaca (22.38\%), dilanjutkan dengan aktivitas bertanya pada teman (20.48\%), aktivitas bertanya pada guru $(8.10 \%)$ dan aktivitas tidak relevan dengan KBM (3.38\%).

Sesuai dengan batasan pada bab III, penelitian tindakan kelas dinyatakan berhasil jika adanya peningkatan ketuntasan individu dan kelas siswa dimulai dari formatif I ke formatif II sehingga dapat disimpulkan bahwa proses pembelajaran menggunakan model pembelajaran kooperatif tipe STAD dapat meningkatkan ketuntasan pembelajaran siswa pada pembelajaran IPA di kelas VIII.B SMP Negeri 3 Bahorok dan berhasil memberi ketuntasan klasikal sampai pada akhir Siklus II. Keadaan tersebut dapat dijadikan sebagai kajian bahwa dengan Siklus yang berulang dan menggunakan model pembelajaran kooperatif tipe STAD memungkinkan meningkatkan ketuntasan pembelajaran IPA siswa. Namun demikian penelitian hanya dilaksanakan sampai pada dua Siklus karena keterbatasan dana dan waktu.

\section{KESIMPULAN}

Berdasarkan analisis data dan pembahasan, maka dapat disimpulkan penerapan model pembelajaran kooperatif tipe STAD dalam pembelajaran IPA di kelas VIII.B SMP Negeri 3 Bahorok Tahun Pembelajaran 2016/2017 bahwa :

1. Hasil belajar siswa meningkat dari siklus I ke siklus II setelah menerapkan model pembelajaran 
Jurnal Guru Kita (JGK). Vol 1 (2) Maret 2017, hlm. 120-127

kooperatif tipe STAD. Pada siklus I terdapat 14 siswa yang tuntas secara individu tetapi kelas belum tuntas sedangkan pada siklus II terdapat 23 siswa yang tuntas secara individu dan tuntas secara kelas. Peningkatan terjadi karena guru memberikan tugas kepada siswa untuk dikerjaan di rumah, hal ini membuat siswa semakin memahami pembelajaran.

2. Terjadi peningkatan rata-rata aktivitas belajar siswa menurut dua pengamat dari siklus I ke siklus II. Aktivitas yang meningkat adalah aktivitas mengerjakan LKS dari $23.00 \%$ menjadi $45.24 \%$ dan bertanya pada teman dari $9.00 \%$ menjadi 20.48\%. Sedangkan aktivitas yang menurun adalah aktivitas menulis, membaca dari $41.00 \%$ menjadi $22.38 \%$, bertanya pada guru dari $16.50 \%$ menjadi $8.10 \%$, dan yang tidak relevan dengan KBM dari $10.50 \%$ menjadi $3.81 \%$. Peningkatan aktivitas terjadi karena setiap siswa sudah memiliki tanggung jawab masing-masing sehingga pembelajaran berjalan sesuai yang diharapkan.

\section{DAFTAR RUJUKAN}

Aqib, Zainal. 2006. Penelitian Tindakan Kelas. Bandung : Yrama Widya.

Isjoni. 2007. Cooperative Learning Efektifitas Pembelajaran Kelompok. Pekan Baru : Alfabeta

Majid, Abdul. 2009. Perencanaan Pembelajaran Mengembangkan Standar Kompetensi Guru. Bandung : PT. Remaja Rosdakarya Offset
Sanjaya, Wina. 2006. Strategi Pembelajaran Berorientasi Standar Proses Mengajar. Jakarta : Kencana Prenada Media.

Slameto. 2001. Belajar dan Faktor-

Faktor yang Mempengaruhinya Jakarta : PT Rineka Cipta.

Slavin, Robert E, 2008. Cooperative Learning;Teori, Riset, dan Praktik. Bandung : Nusa Media,

Subino. 1987. Kontruksi dan Analisis Tes. Bandung : Tarsito. 